\title{
Just In Time and Service Quality
}

\author{
Engr. Michael .D. Oisamoje, $\mathrm{PhD}^{1}$, Wogu .E. Onyekachi ${ }^{2}$ \\ ${ }^{\text {I}(D e p a r t m e n t ~ o f ~ B u s i n e s s ~ A d m i n i s t r a t i o n, ~ B e n s o n ~ I d a h o s a ~ U n i v e r s i t y, ~ B e n i n ~ C i t y, ~ N i g e r i a) ~}$ \\ ${ }^{2}$ (School of Postgraduate Studies, Benson Idahosa University, Benin City, Nigeria)
}

\begin{abstract}
Every business entity strives to be cost efficient in spite of stiff competition. This is in order to remain profitably in business and possibly distinguish itself. The just-in-time (JIT) approach is $x$-rayed as it applies not only to manufacturing or production industries but also to the services industry. This is because it relates to processes involved before its final delivery. It's meanings as put forward by various individuals and bodies were expressed. The importance of JIT as it relates to improved service quality was highlighted and the challenges of its implementation by management were discussed. Some models were used to illustrate JIT in services. The paper rounds up with conclusions as to the need for total embrace of what JIT offers to businesses in the services industry. How to mitigate the challenges affecting the capability of Nigerian firms to apply JIT principles and strategies were also recommend.
\end{abstract}

Keywords : Just in time (JIT), processes, relevance, services industry, service quality

\section{Introduction}

The services industry as with the manufacturing industry require continuous improvement in its methods of doing business to ensure sustained profit and increase in its service reach. Usually, businesses create warehouses for storage of inventory that would enable it render effective services without disruption in the delivery process.

Industry operatives have come to acknowledge the place of the buffer stocks as an approach or instrument for protection $\mathrm{g}$ against uncertainties associated with inventory lead time, that is, the time or duration between the initiation of a replacement order and reception of the order [1]. Just in time approach offers businesses the advantage of reduced costs by purchasing just enough materials needed to meet the daily services thereby reducing cost to its minimum level.

The concept of just in time was seen to have gained international awareness especially from the west with its successful adaptation and outstanding results achieved by the Toyota production system (TPM) which was invented as well as promoted by Taichi Ohno in the 1960s in Japan. Just in time emphasizes simplifying the production process so as to quickly detect problems and be forced to find immediate solutions to resolve these problems.

The services industry stands to benefit a lot from this concept as it avails it the opportunity of engaging in just in time partnerships. Hence it is canvassed that purchasers and suppliers need to work hand in hand with the sole aim of eradicating waste as well as driving down cost for their mutual benefits [2]. Hence [3] argues that the JIT concepts and techniques are equally applicable to both manufacturing and service operations because they are process rather than product oriented. [4] further confirms that as both service and manufacturing firms employ processes with the aim of producing an end product or service, JIT practices should be applicable to both sectors. The authors [4] also report six practices of JIT systems which from their perspective are applicable to services. These six practices are as follows:

i. Synchronization and balance of information and work flow;

ii. Total visibility of all components of the process;

iii. Continuous improvements of the process;

iv. Holistic approach of elimination of waste;

v. Flexibility of the use of resources;

vi. Respect for people.

According to [5], the increasing global competition, emerging new technologies and enhanced communications have resulted in increased customers' expectation of maximum satisfaction with the products and services they purchase. As a result the trends amongst companies have shifted towards increasing customer satisfaction as well as the quality of products or services offered. The just in time approach therefore seeks to efficiently and effectively handle these above concerns while ensuring minimum cost. 


\subsection{Reasons That Give Rise to Just In Time Approach to Inventory Control}

According to [6], some reasons that have been adduced for the increasing application of JIT approach

to inventory control are:

i. Inaccurate quantities

ii. Scrap

iii. Rework

iv. Poor floor layout

v. Downtime

vi. Unstable demand and others.

\section{Definitions of Just In Time}

Just in time (JIT) as defined by [6] is a disciplined approach to improving overall productivity and eliminating waste. It provides for the cost-effective production and delivery of only the necessary quantity of parts at the right quality, at the right time and place, while using a minimum amount of facilities, equipment, materials and human resources.

According to [7] Just in time is a system whose objective is to produce or to procure products or components as they are required by a customer or for office use rather than for storage. It is a pull system that responds to demand. They opine further that just in time purchasing is a system that enables the contracting of material purchases such that the receipts as well as usage of materials coincide to the maximum possible extent.

The business dictionary defined Just In Time as a pull (demand) driven inventory system in which materials, parts, sub-assemblies, and support items are delivered just when needed and neither sooner nor later. On his part, [5] has defined just in time as simply a planning concept designed to eliminate waste. Reinforcing this assertion, [8] explains that Just In Time is a business approach/philosophy of supplying a product or service when it is needed, how it is needed and in the exact quantity it is needed. Put simply, Just in time means rendering service right when it is demanded at the right time, at the right quantity, at the right quality and at the right price. The above stated specific definitions become necessary owing to the fact that our emphasis is on just in time in services industry.

\subsection{Distinguishing Features of Just In Time in Inventory Control}

The following reasons peculiar to the just in time inventory technique:

i. Waste reduction: This is achieved via the supply of materials as demanded at the right quantity and price.

ii. Variability reduction: This means the reduction of deviations which often goes unnoticed when inventory exists.

iii. Pull system of operation: It is a situation where supplies are only made when a demand exists.

iv. Ensures quality delivery: It thrives via joint partnership between the producer and the supplier on zero tolerance to sub standards

v. People involvement

vi. Zero inventory. This is an ultimate stage which indicates that the above features are effectively and efficiently implemented.

\subsection{Distinguishing Features of a Service from a Product}

According to [5] these features include:

i. Inseparability of production and consumption

This involves simultaneous production and consumption which characterizes many services. Thus, emphasizing the Importance of process control in services.

ii. The customer is a participant in the production process.

The customer is always involved in service production process, though the degree of customer involvement may vary from high to low contact.

iii. Intangible

Because services are performances, ideas or concepts rather than tangible items hence the customer must rely on the reputation of the service firm.

iv. Perishability

This refers to the concept that a service cannot be saved or stored as inventory

v. Heterogeneity

As a result of explicit and implicit service elements services relays on individual preferences and perceptions. 
vi. Labour intensive which implies a lot of manpower involvement in services rendering.

The above distinctions are vital as to enhance further understanding of the uniqueness of the services sector in terms of mode of service delivery.

\subsection{Service}

While [9] considers a service to be an economic activity that adds value either directly to another economic unit or to a good belonging to another economic unit, [10] points out the fact that there could arise confusion owing to the various meanings attributable to the word service. Arguing further, [10] opines that Service could be an industry, a performance, an output or offering or a process and also revealed that services usually entail a mix of both tangible and intangible aspects or components. In the opinion of [11], Services are activities undertaken to help the customer attain value.

\subsection{Quality}

Quality is of the essence in consideration of JIT processes, strategies and activities. It is therefore important to examine a number of definitions and perceptions of what quality entails.

Quality has simply been defined as the feature that makes something fit for use [12]. Thinking differently, [13] refers to quality as the extent to which processes, products, services, and relationships are free from defects, constraints, and items which do not add value for the customer. Quality may be perceived in [14] as a judgment by customers or users of a product or service, and it is the extent to which the customers or users believe the product or service surpasses their needs and expectations.

Other authorities like [15] perceive quality as the totality of features and characteristics of a product that bear on its ability to satisfy stated or implied needs, [16] conceives quality as the total composite product and service characteristics of marketing, engineering, manufacture and maintenance through which the product in use will meet the expectations of the customer. [17] declares that quality is anything which can be improved, while [18] regards quality as the loss a product causes to society after being shipped.

Although it has been argued that quality must be defined as conformance to requirement [19], quality may also be considered as the degree or grade of excellence possessed by a thing, or its peculiar excellence or superiority; capacity, ability or skill [20]. While it is almost impossible to give an all-embracing definition of quality, perhaps because of its versatile nature, some authorities [21] see quality as the summation of the affective evaluations by each customer of each attitude of the object that creates customer satisfaction. Adding to the discussion, [22] describes quality as the totality of features and characteristics in a product or service that bear upon its ability to satisfy needs.

\subsection{Service Quality}

In real terms, quality is often not defined or conjured in isolation. It is usually invoked in relation to some other features, attributes or relationships. Hence reference is often made to the quality of security, the quality of governance, the quality of transparency, the quality of product, and so on. Putting this in context, this section focuses on the quality of service which can be defined as a measure of how well the service delivered matches the customer expectation of the service [23].

[24] explain that service quality is an approach to manage business processes in order to ensure full satisfaction of the customers and quality of service provided. [24] also confirm further that service quality works as an antecedent to customer satisfaction. Service quality has been defined by [11] as the gap that is perceived to exist between the expectations and the perception of the service experienced.

Service quality sometimes just identified as 'SERVQUAL', a service quality framework developed by [25], has been identified as consisting of the following five evaluation criteria illustrated in Figure 1:

Gap 1: Gap between customer expectation and management service perception

This gap arises when management is unable to correctly understand the want of customers.

Gap 2: Gap between management perception and service quality specification

This gap results when management overcomes the gap 1without corresponding it with setting performance standards.

Gap 3: Gap between service quality specification and service delivery

This gap occurs when gaps 1 and 2 have been tackled but training of service personnel is lacking and inability to meet the set standards.

.Gap 4: Gap between service delivery and external communication

This gap exists when there is a disparity between the advertised service and customer experience with service delivered.

Gap 5: Gap between expected service and experienced service 
This gap is the result of customer misinterpretation of service quality, it can also be seen as a definition of service quality which is determined by the customer actual experience of service meeting or exceeding expected service.

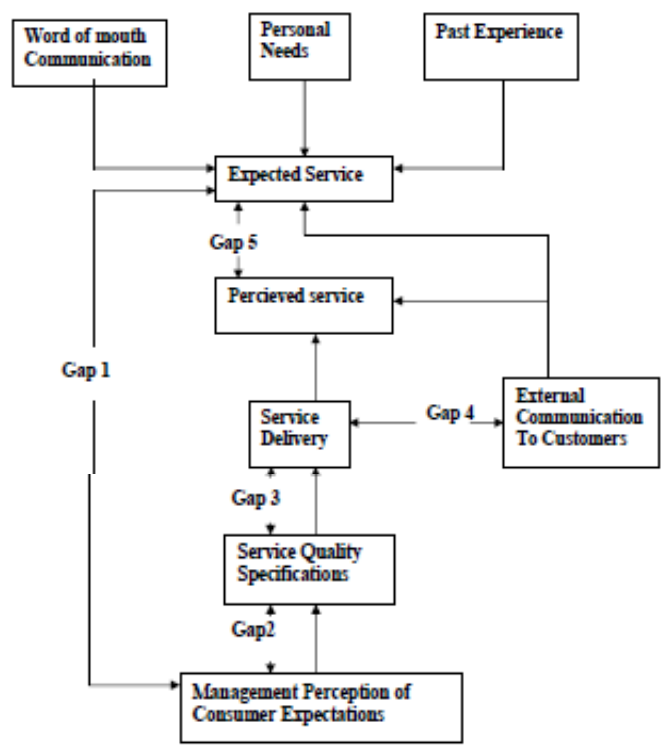

Figure 1: Just In Time Service Quality Model in Service Organizations. Source: Gupta (2011:2225) [5].

\subsection{Relevance of Just In Time in Service Quality}

According to [5], the dimensions collectively measure the degree of JIT used in any service organization and consequently the level of service quality.

1. Synchronisation: This entails the service organizations effectively balancing their service supply and demand thus reducing the gap 2.

2. Flexibilility: This refers to ability to respond to sudden changes in customer needs and requirements as it occurs. As a result staff must be in place flexible staffing and good supplier relationships. This leads to a reduction in gap 2

2. Quality: The goal of JIT is geared towards quality hence a lot of care should be taken to train employees on rendering efficient service knowing first impression is key. This in turn enables a reduction in gap 3

3. Simplified procedures: This entails cutting down anytime which does not add value to the service delivery process (waste) which JIT sets out to achieve. This results in a reduction in gap 3

4. Service design for JIT: Team work is a very vital part of ensuring the success of JIT, also ensuring quality, reduced cost, prompt service delivery are important ingredients in reducing gap 3

5. Continuous improvement (Kaizan): JIT focuses on the process of product or service delivery and we are concerned about service delivery. It therefore presupposes that since the business is an entity existing in a dynamic environment improvement the JIT way is inevitable as it must be sustained in order to yield its benefits or results.

6. Employees involvement and training: In order to tackle the gap 3, it becomes expedient that staff be trained on effective service delivery geared towards customer satisfaction. It becomes necessary that a strong team of same minded people be built where customer satisfaction is concerned.

7. Standardization: This entails bring in same quality in service delivery in order to save time and possible discrepancies in process of delivery. This is achieved bearing in mind the dynamic nature of customer need, thus reducing gap 3 . 


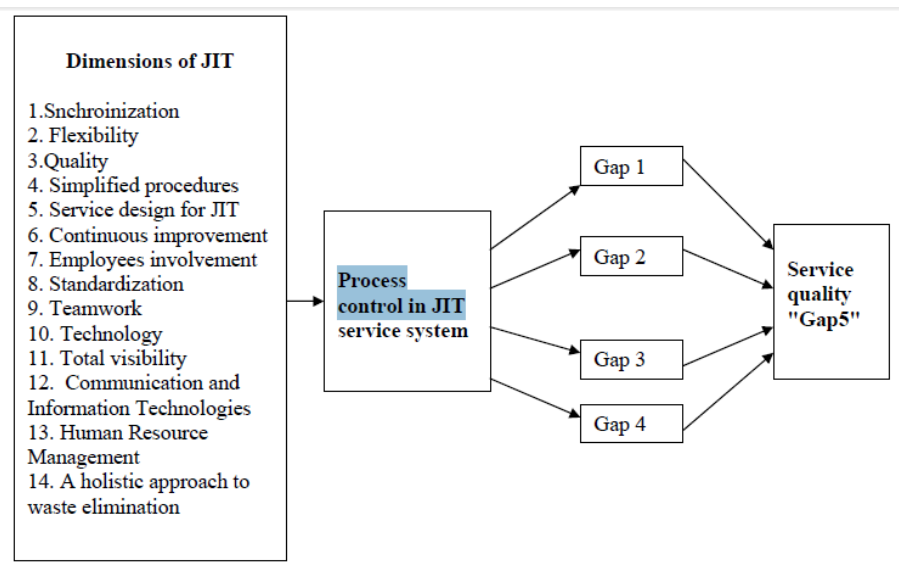

Figure 2: Model and Main Variables of JIT and Service Quality in JIT. Source: Gupta et al (2011) [5].

8. Teamwork: Every member of the organization should be seen as a valid part of the team and hence should be actively involved in effective service delivery process in line with JIT requirements. Everyone's ideas as well as contributions should be regarded thus improving quality of work life and reducing gap 3 .

9. Technology: Improvement or advancement in technology should be embraced as it seems fit for the organization as a tool to support employee rendering effective and efficient service, thus reducing gap 3 and 4. It is important however to note that customer acceptance is vital in introduction of technology.

10. Total visibility: Quality service always portrays an excellent image about an organization and in addition to good marketing via advertising, customer perception is usually affected. This results in reduction of gap 4.

11. Communication and information technologies: Communication amongst staff as to the expectations of service to be rendered, their opinions or suggestions as regards the service. It is important that information technologies like email, phones be encouraged to facilitate quick and prompt response and communication. Also proper evaluation of service process, customer satisfaction or dissatisfaction, performance can be accurately estimated by use of tools such as statistical quality control (SQC) etc. Data obtained can be valuable use in reducing gaps 1,3 and 4

12. Human resource management: Investment by management in its employees is key in order to ensure a successful implementation of JIT. Training of human resource, consequent promotion as well as some level of independence in decision making, encouraging initiative after already instilling the organizational service culture are various ways to reduce the gaps 1,2,3 and 4

13. A holistic approach to waste elimination: In order to reduce gaps $1,2,3$ and 4 it becomes necessary to identify anything that does not add value to the service process (waste) and get rid of them. The JIT technique major objective being elimination of waste must of necessity be applied to every aspect of the service process.

\section{Challenges in the Implementation of Just In Time}

The following were put forward by [26] as some of the challenges related to JIT:

i. Resistance of the management due to lack of resources.

ii. Change in the whole system is a difficult task.

iii. Most Institutions are interested in product innovation rather than process innovation.

iv. Lack of qualified and trained staff.

v. Union's fear of loss of jobs and resistance to multifunctional employee concept can act as a deterrent.

In order to mitigate these challenges [26] suggests the following:

i. Management of institutions should make careful planning for an efficient management system.

ii. Such managements should recognise that the just in time system, in the long run, offers the potential of tremendous savings in areas of overhead and material reduction, thereby resulting in overall reduction of wastage of all kinds.

\section{Conclusion}

The importance of quality in service cannot be overemphasized as it gives the cutting edge to corporate organizations in the service industry that are poised to have strong competitive advantage in a global environment. This distinguishes between firms that would stand out and those that would only just operate on the periphery. Customers' demands as well as expectations of quality over the years have continued to increase. Therefore the adoption of JIT by businesses in the services sector is a bold step in the right direction which has the ultimate objective of maintaining excellence and retaining continued customer patronage. It is also 
imperative that institutions managements move past the acting the mediocre to deciding to excel as well as stand out by restructuring their business process the JIT way.

It is essential to note that the use of just in time in ensuring service quality is a continuous process bearing in mind the dynamic nature of the external environment and customers' needs. The need for continuous research on how to make JIT relevant to today's businesses can therefore not be over-emphasised. The obvious challenge that many Nigerian firms face in implementing the JIT concept are many, but include attitudinal issues as well as the lack of adequately developed infrastructural facilities required to drive the JIT process. Another vital factor is the so called 'Nigerian factor', a metaphor for a huge continuum of social vices ranging from institutionalized bribery and corruption to tribalism and nepotism. A functional and reliable educational system is a sine qua non for an effective application of JIT in any economy.

\section{References}

[1]. F.S. Budnick, D. Mcleavey, R. Mojena, Principles of operations research for management (Irwin, Homewood, Illinois, 1988).

[2]. J. Heizer, B. Render ( Ed), Operations management, 7th ed. (New jersey: Pearson Education Inc, 2004).

[3]. Canel, D. Rosen, E. A. Anderson, Just-in-time is not just for manufacturing: a service perspective, Industrial Management + Data Systems, 100(2), 2000, 51-60

[4]. Duclos, L.K., Siha, S.M. and Lummus, R.R, JIT in services: a review of current practices and future directions for research, International Journal of Service Industry Management, 6(5 ), 1995, 36-52 in H.Wael, Just in time system in services, doctoral symposium, UK Brunel Business School, 2011

[5]. A.K Gupta, A conceptual JIT model of service quality, International Journal of Engineering Science and Technology, 3(3), 2011, 2214-2227.

[6]. N. Slack; S. Chambers; C.Harland; A. Harrison; R. Johnston, Operations management (London: Pitman publishing, 1995).

[7]. Chartered Institute of management Accounting, Professional examination intermediate, paper 4, Costing and quantitative techniques, (Lagos: VI publishers, 2009).

[8]. Y. Monden, Toyota Production System: A practical approach to production management, Industrial Engineering and Management Press, Atlanta. 1983 in A.K Gupta, A conceptual JIT model of service quality, International Journal of Engineering Science and Technology, 3(3), 2011, 2214-2227.

[9]. T.P Hill, On Goods and Services, Review of Income and Wealth, 24(4), 1977, 315-317 in G. Hufbauer and T. Warren, The globalization of services: What has happened? What are the implications? paper presented at the International Conference of Private Business Organizations, The Service Economy: An Engine for Growth and Employment, by the Institut der Deutschen Wirtschaft Koln, in Dresden, 1999

[10]. N. Johns, What is this thing called service?, European Journal of Marketing, 33(9/10), 1998, 958-973 in C. N. Daniel and L. P. Berinyuy Using the SERVQUAL Model to assess Service Quality and Customer Satisfaction (2010).

[11]. J. Hirmukhe, Measuring internal customers' perception on service quality using the SERVQUAL in administrative services, International Journal of Scientific and Research Publication, 2(3),2012, 1-6.

[12]. J. M. Juran, A History of Managing for Quality (Milwaukee, Wisconsin: ASQC Quality Press, 1995) in M. G. Pryor, L.Toombs, D. Anderson, J.C. White, What management and quality theories are best for small businesses?, Journal of Management and Marketing Research , 1-12 (n.d.)

[13]. M. G. Pryor, J.C. White, L.A. Toombs, Strategic Quality Management: A Strategic, Systems Approach to Quality (Thomson Learning, 1998) in M. G. Pryor, L. Toombs, D. Anderson, J.C White, What management and quality theories are best for small businesses?, Journal of management and marketing research , 1-12 (n.d)

[14]. H. S. Gitlow, S. J. Gitlow, A. Oppenheim, R. Oppenheim, Tools and methods for the improvement of quality. (Richard D. Irwin Inc, Homewood, 1989) in T. O. Manani, R. B. Nyaoga, R. M. Bosire, T. O. Ombati, T. O. Kongere, Service Quality and Customer Satisfaction, European Journal of Business and Management,5(22), 2013,170-179

[15]. International Standards Organisation, Quality management and quality assurance vocabulary, ISO 8402, 1994.

[16]. A. V. Feigenbaum, Total Quality Control: Engineering and management (McGraw-Hill, New York, 1986).

[17]. M. Imai, Kaizen (New York: McGraw-Hill, 1986) in J. Freiesleben, On the Profitability of Technology-Rooted Delivery Quality, Dissertation Der Universit T St. Gallen, Hochschule F R Wirtschafts-,Rechts- Und Sozialwissenschaften (Hsg) Zur Erlangung Der W Rde Eines Doktors Der Wirtschaftswissenschaften.

[18]. S.Taguchi, D.M. Bryne, 1986, The Taguchi Approach to Parameter Design, ASQC Quality Congress Transactions, Anaheim, CA, in R. Unal, E.B. Dean, Taguchi approach to design optimization for quality and cost: an overview, Presented at the 1991 Annual Conference of the International Society of Parametric Analysts.

[19]. P. Crosby, Quality is Free (McGraw-Hill Book Company, New York, 1979) in M. G. Pryor, L. Toombs, D. Anderson, J.C White, What management and quality theories are best for small businesses?, Journal of management and marketing research , 1-12 (n.d)

[20]. A. Stevenson (Ed.), Shorter Oxford English Dictionary, 6th ed., (Oxford: Oxford University Press, 2007).

[21]. A. M. Wicks, C. J. Roethlein, A satisfaction-based definition of quality, Journal of Business \& Economic Studies,15(1), 2009, 82-97 in Z. Rahimić, K. Uštović, Strategic quality management on business to business market in Bosnia and Herzegovina, BEH - Business and Economic Horizons, 6(3), 2011, 1-17

[22]. S. Haider, ISO 9001: 2000 Document Develpment Compliance Manual. (Florida: St. Lucie Press, 2001), in A. J. Lubasha, S. K. Tripathi, Vocational Education Program Quality in Tanzania: Study of Stakeholders Perception in Dar Es Salaam Region, International Journal of Management \& Information Technology, 1(3), 2012, 118-132

[23]. R. C. Lewis, H. B. Bernard, The marketing aspects of service quality, American Marketing, 1983, 99-107.

[24]. K. D. Ruyter, J. Bloemer, Integrating Service Quality and Satisfaction: Paying in the Neck, or Marketing Opportunity?, Journal of Consumer Satisfaction, Dissatisfaction and Complaining Behavior, 8, 1995,44-52.

[25]. A. Parasuraman , V. Zeithaml , L.L Berry, SERVQUAL, A multiple item scale for measuring Perceptions of Service Quality, Journal of Retailing, 64( 1),1985, 12-40

[26]. V. Panchal, A. Gupta, S. Ram, N. Rai, Identification of JIT elements in services sector, International Journal of Latest Research in Science and Technology, 1(3), 2012, 211-214. 